\title{
Stability Enhancement of a Hybrid Micro-grid System in Grid Fault Condition
}

\author{
Mir Nahidul Ambia *, Ahmed Al-Durra **, Cedric Caruana *** and S.M. Muyeen****
}

\begin{abstract}
Low voltage ride through capability augmentation of a hybrid micro-grid system is presented in this paper which reflects enhanced reliability in the system. The control scheme involves parallel connected multiple ac-dc bidirectional converters. When the microgrid system is subjected to a severe voltage dip by any transient fault single power converter may not be able to provide necessary reactive power to overcome the severe voltage dip. This paper discusses the control strategy of additional power converter connected in parallel with main converter to support extra reactive power to withstand the severe voltage dip. During transient fault, when the terminal voltage crosses $90 \%$ of its pre-fault value, additional converter comes into operation. With the help of additional power converter, the micro-grid system withstands the severe voltage fulfilling the grid code requirements. This multiple converter scheme provides the micro-grid system the capability of low voltage ride through which makes the system more reliable and stable.
\end{abstract}

Keywords: Micro-grid, Low voltage ride through, Reliability, wind power generation system, PV system.

\section{Introduction}

At the present growing demand of electricity, widespread tripping of wind generators followed by disturbances can be one of the reasons of propagation of transient instability [1]. In terms of voltage stability, low voltage ride through is one of the most important issues. Due to lack of reactive power support, the possibility of voltage collapse is a critical issue. To withstand this kind of severe voltage dip, low voltage ride through capability (LVRT) has become a great requirement to be fulfilled in the grid codes [2-5].

In the present power scenarios, when it is mentioned about distributed generations of small scale generations to meet the customer demand, the coordination of these small scale generations consisting wind, photovoltaic, batteries and fuel cells are formed as Micro-grid [6-9]. Interest is rapidly increasing for micro-grid as it is based on the renewable energy sources, which connects the utility grid. In the grid tied mode, it is connected with utility whereas in case of islanded mode it is totally disconnected. In case of

\footnotetext{
Dept. of Electrical Engineering, The Petroleum Institute, UAE. (nahidul.ambia@gmail.com)

** Dept. of Electrical Engineering, The Petroleum Institute, UAE. (aaldurra@pi.ac.ae)

*** Faculty of Engineering, University of Malta, Malta. (cedric.adpi@gmail.com )

****Dept. of Electrical Engineering, The Petroleum Institute, UAE. (smmuyeen@pi.ac.ae)

Received 13 December 2012 ; Accepted 16 May 2013
}

islanding mode it becomes totally independent and fulfills. the customers' demands from the renewable energy sources. Even in the micro-grid the capability of low voltage ride through is of great importance. During the transient instability, the system has to withstand the severe voltage dip in order to enhance the stability and reliability of the system. In this paper, the low voltage ride through capability of the micro-grid system has been focused keeping in mind that the enhancement of the reliability of the system is an important issue. The control scheme is designed to make the micro-grid system more reliable and efficient during transient conditions. The concept of parallel units of converters has been introduced so that during the transients when the terminal voltage crosses $90 \%$ of its prefault value, additional power converter can come into operation. The additional power converter supports extra reactive power needed to withstand the severe voltage dip. One case is shown out of the several in the simulation section. In the Section II and III, the proposed micro-grid system and dynamic system modeling are described. Section IV shows control strategy which explains how the alternate converter takes part in operation during the transient disturbance and how it gets back to its pre-fault state. Grid code is explained briefly in Section V. In Section VI, responses are shown to achieve the targets of the microgrid system and finally the conclusions are made in the last section. 


\section{Proposed Micro-grid System}

A hybrid micro-grid system has been proposed and shown in Fig. 1 which consists of AC grid on the left and DC grid on the right side. Induction generator of $5 \mathrm{MW}$ power is connected at the ac side which is driven by fixed speed wind turbine. Fuel cell and Photovoltaic cells are connected as the dc source and Energy storage system is connected as well. Both ac and dc loads are considered in the system and whole system is connected with utility grid.

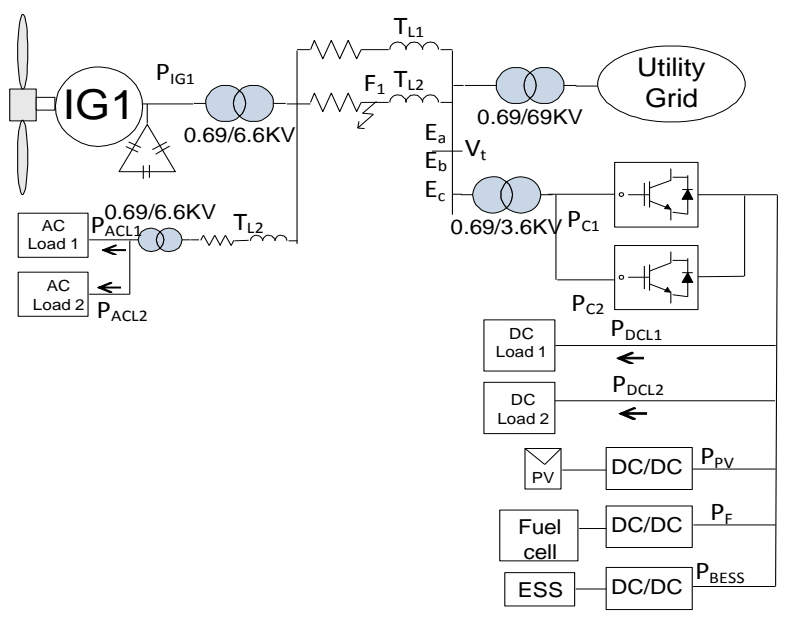

Fig. 1. Proposed ac-dc hybrid micro-grid model system

Table1. Micro-grid parameters

\begin{tabular}{|l|l|}
\hline \multicolumn{1}{|c|}{ Parameters } & \multicolumn{1}{c|}{ Value } \\
\hline Base voltage of converter & $3.6 \mathrm{kv} \mathrm{V} \mathrm{VL}_{\mathrm{LL}}$ \\
\hline Base current of converter & $0.40093 \mathrm{~A}$ \\
\hline Resistance (TL1) & $0.26368 \mathrm{ohm}$ \\
\hline Inductance (TL1) & $0.0004326 \mathrm{H}$ \\
\hline Length (TL1) & $2.06 \mathrm{~km}$ \\
\hline Resistance (TL2) & $0.013312 \mathrm{ohm}$ \\
\hline Inductance (TL2) & $0.0002184 \mathrm{H}$ \\
\hline Length (TL2) & $104 \mathrm{~m}$ \\
\hline AC generation & $5 \mathrm{MW}$ \\
\hline DC generation & $0.5 \mathrm{MW}$ \\
\hline PWM carrier frequency & $1000 \mathrm{~Hz}$ \\
\hline AC loads & $3 \mathrm{MW}$ \\
\hline DC loads & $2.5 \mathrm{MW}$ \\
\hline DC link voltage & $6.6 \mathrm{kv}$ \\
\hline DC link capacitance & $100000 \mu \mathrm{F}$ \\
\hline
\end{tabular}

Fuel cell and energy storage system is connected by DCDC boost converter at the dc bus whereas the solar cell is connected with DC-DC boost converter in order extract maximum power. Reactive power compensation at the grid voltage terminal can be handled by bidirectional AC-DC converter which is the main focus in this system as the additional converter along with the main converter play an important role for achieving the low voltage ride-through capability. During the transient disturbance the additional converter comes into operation and provides necessary reactive power to withstand the severe voltage dip leading to an enhanced stable and reliable system.

The induction generator delivers $5 \mathrm{MW}$ and solar cell generates $0.5 \mathrm{MW}$ amount of power [10-12]. The total generation is distributed to the ac and dc loads through parallel bi-directional ac-dc converters. Capacitor bank is used to maintain unity power factor operation at the rated wind speed. Micro-grid parameters are given briefly in Table I. In the simulation, fuel cell and ESS at dc bus is not considered.

\section{Dynamic System Modeling}

\subsection{Wind Turbine Modeling}

Wind turbine is an electromechanical energy conversion device that is capable of capturing kinetic energy from the wind and can turn this energy into electrical energy. In order to model the wind turbine, its components consist of turbine rotor or prime mover, a shaft and a gearbox unit [13, 14]. The wind turbine output torque and extracted power from the wind turbine can be expressed by [12-16] below equations.

$$
\begin{gathered}
T_{m}=\frac{1}{2} \cdot \rho C(\lambda) \pi R^{3} V_{W}{ }^{2}[N M] \\
P_{m}=\frac{1}{2} \cdot \rho C_{P}(\lambda, \beta) \pi R^{2} V_{W}^{3}[W]
\end{gathered}
$$

Where $\rho$ is the air density, $\mathrm{R}$ is the radius of the turbine, $\mathrm{V}_{\mathrm{W}}$ is the wind speed, $\mathrm{C}_{\mathrm{P}}(\lambda, \beta)$ is the power coefficient given by

$$
C_{P}(\lambda, \beta)=\frac{1}{2} \cdot\left(\Gamma-0.02 \beta^{2}-5.6\right) e^{-0.17 \Gamma}
$$

Where, $\Gamma=\frac{R(3600)}{\lambda(1609)}$ and $\lambda=\frac{\omega_{m} R}{V_{w}}$ is the tip speed ratio. The relationship between $\mathrm{C}_{\mathrm{t}}$ and $\mathrm{C}_{\mathrm{p}}$ is

$$
C_{t}(\lambda)=\frac{C_{P}(\lambda)}{\lambda}
$$

\subsection{Solar Panel Modeling}

Each photovoltaic cell consists of a diode, a current source, a series resistance and a parallel resistance which is the basic element of a solar model. The photo current produced from the current source is dependent upon the solar cell radiation and temperature. p-n junction of a solar cell is represented by the diode. The photovoltaic cell current equation can be expressed as [20].

$$
I_{P V}=n_{P} I_{P h}-n_{P} I_{r s}\left[e^{\left(\frac{q V_{d c}}{K T_{C} A n_{S}}\right)}-1\right]
$$


Where,

$$
\begin{gathered}
I_{r s}=I_{r r}\left[\frac{T_{c}}{T_{r}}\right]^{3} e^{\left(\frac{q E_{s}}{K A}\right)\left(\frac{1}{T_{r}}-\frac{1}{T}\right)} \\
I_{p h}=0.01\left[I_{s c r}+K_{v}\left(T_{c}-T_{r}\right)\right] s
\end{gathered}
$$

Where, $\mathrm{nS}$ and $\mathrm{nP}$ are the number of cells connected in series and parallel respectively. Iph is the photo current, Irs and Irr are reverse saturation current at $\mathrm{T}$ and $\mathrm{Tr}$. $\mathrm{T}$ is cell temperature and $\mathrm{Tr}$ is reference temperature. Iscr is the cell short circuit current at $\operatorname{Tr}$. $\mathrm{S}$ stands for irradiance in $\mathrm{mw} / \mathrm{cm} 2 . \mathrm{K}$ is Boltzmann constant, $\mathrm{Kv}$ is the short circuit temperature coefficient at Iscr and $\mathrm{q}$ is charge of electron. $\mathrm{A}$ is the identity factor. IPV is current from the photovoltaic cell.

\subsection{Fuel Cell Modeling}

Fuel cells are electrochemical devices which convert the chemical energy of a reaction into electrical energy. A fuel cell basically consists of an electrolyte layer (Ion conductor) in between a porous anode and cathode. Electric current is produced from the electrochemical reactions at the electrode, when gaseous fuel is injected to the anode and oxidant is fed to cathode [21-22].

\subsection{Fuel Cell Modeling}

Energy storage device which is also known as ESS is a device which can store energy and discharge energy during its operation. Nowadays it has become an important part in wind farms and photovoltaic cells in micro-grids.

When demand is greater than the generation ESS can deliver energy in the system and it is also used to smoothen the power of wind farms. In the proposed micro-grid system, ESS is considered to be connected at the terminal of fixed speed wind turbine generator system which ensures constant power delivery by absorbing the fluctuating quantity of the wind power as shown in Fig. 2. According to [23], the ESS charges the first half cycle of the variable power and then discharges it at the next cycle so that the constant power can be delivered to the power grid.

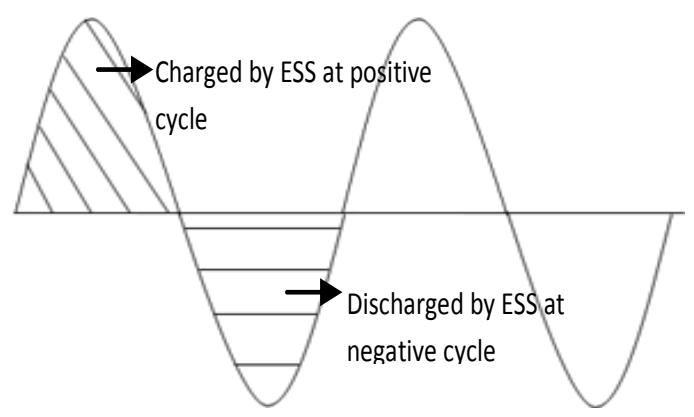

Fig. 2. Wind power smoothing operation by ESS

\section{Control Strategy}

To enhance the stability of the hybrid micro-grid system during transient condition, control strategy has been used. During the steady state condition, single power converter operates. When transient fault occurs, the micro-grid experiences a severe voltage dip. To withstand this severe voltage dip, additional converter is used to provide extra reactive power. After the transient fault, when the terminal voltage decreases to $90 \%$ of its pre-fault value, the additional converter is switched on so that it can provide necessary reactive power support.

Figure 3(a) shows the control block diagram of individual power converter unit, where PLL provides the angle $\theta_{\mathrm{PLL}}$ for the abc-to-dq0 (and dq0-to-abc) transformation. This control block is interlinked with the power converter reference control scheme which is shown in detail in Fig. 3(b). At steady state, real power through the power converter $\mathrm{P}_{\text {REF_CONV }}$ is controlled and reactive power through the power converter $\mathrm{Q}_{\mathrm{ref}}$ is forcefully made zero. When transient fault occurs the real power through the power converters $P_{\text {REF_CONV }}$ and terminal voltage $V_{t}$ is controlled. This way, the power converters provide reactive power to withstand the voltage dip.

A test case for having the low voltage ride through capability of the micro-grid system using multiple converter schemes is summarized in Table II.

Table 2. Micro-grid Details

\begin{tabular}{|c|c|c|c|c|c|c|}
\hline AC/DC & Generations & \multicolumn{2}{|c|}{ Loads } & \multicolumn{2}{c|}{ Converters } & $\begin{array}{c}\text { Total } \\
\text { Loads } \\
\text { (MW) }\end{array}$ \\
\hline & & L1 & L2 & PC1 & PC2 & 3 \\
\hline AC & 5 & 1.5 & 1.5 & 2 & 0 & 2.5 \\
\hline DC & 0.5 & 2 & 0.5 & & & 3 \\
\hline \multicolumn{7}{|c|}{ During transient analysis } \\
\hline AC & 5 & 1.5 & 1.5 & 1 & 1 & 3.5 \\
\hline DC & 0.5 & 2 & 0.5 & & & 2.5 \\
\hline Total & 5.5 & & & & & \\
\hline
\end{tabular}

In the test case shown in Table II, it is seen that during steady state condition, one power converter is operating and other power converter is turned off. The real power through converter $1, \mathrm{P}_{\mathrm{C} 1}$ is $2 \mathrm{MW}$ and converter 2 is $0 \mathrm{MW}$. During the transient condition, additional converter 2 is turned on and real power through each converter is $1 \mathrm{MW}$. The control strategy shown in Fig. 3(a) discusses the control strategy of each converter. As mentioned earlier, during the transient fault, additional converter is turned on and terminal voltage $\mathrm{V}_{\mathrm{t} \_ \text {ref }}$ control is set from $\mathrm{Q}_{\text {ref }}$ control. This operation is performed by the power converter reference control block shown in Fig. 3(b).

The control strategy of the power converter reference 
control block is shown in Fig. 3(b). This control is developed for the test case shown in Table II. During steady condition the real power reference through each converter, $\mathrm{P}_{\mathrm{C} 1 \text { (ref) }}$ and $\mathrm{P}_{\mathrm{C} 2 \text { (ref) }}$ is set $2 \mathrm{MW}$ and $0 \mathrm{MW}$ respectively. Both the reactive power through each converter, $Q_{1}$ ref(pu) and $\mathrm{Q}_{2 \_ \text {ref(pu) }}$ is set as zero. When terminal voltage reaches less than $0.90 \mathrm{pu}$, the real power through the power converters $\mathrm{P}_{\mathrm{C} 1(\mathrm{ref})}$ and $\mathrm{P}_{\mathrm{C} 2 \text { (ref) }}$ are changed to $1 \mathrm{MW}$. Terminal voltage control is set by providing the reference for the terminal voltage as $\mathrm{V}_{\mathrm{t} \_ \text {ref }}=1$. This operation by providing real power reference turns on the additional power converter. Terminal voltage reference enables the additional power converters along with the converter 1 to provide necessary reactive power to withstand the severe voltage dip.

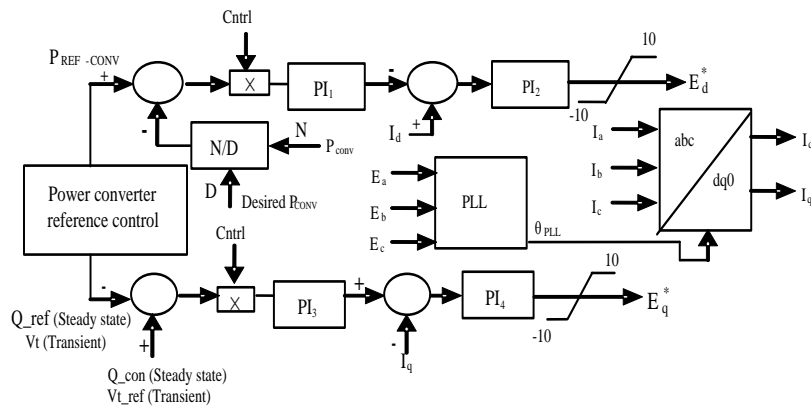

(a)

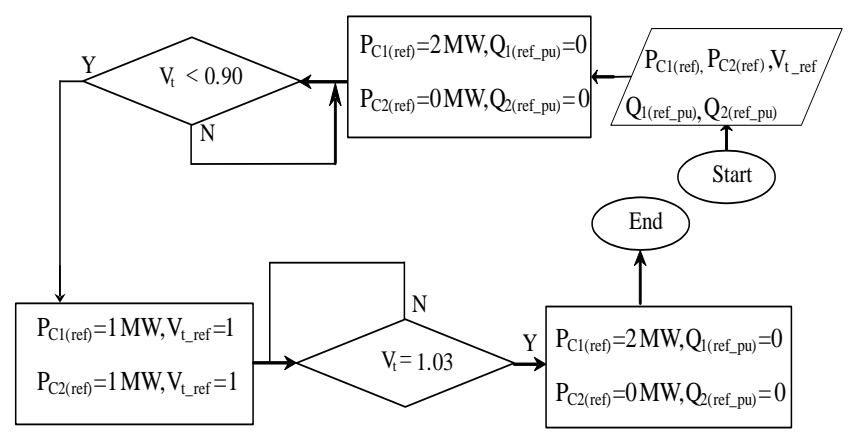

(b)

Fig. 3. (a) Real and reactive power control of power converters with load management control

(b) Power converter reference control scheme

When the terminal voltage reaches to its pre-fault value, the reference signals are set back to the previous state and additional converter is automatically turned off.

\section{Grid Codes}

The most worrying problem that wind farm must face is a voltage dip in the grid during grid fault. The magnitude of the voltage is controlled by the reactive power exchange, since in most networks as $\mathrm{Q} \alpha \Delta \mathrm{V}$. Grid code requirement for low voltage ride through has to take into consideration. According to [24-25], $1.5 \mathrm{sec}$ is considered as the threshold time within which grid voltage should recover $90 \%$ of its pre-fault level. System that can recover within that threshold time is considered as stable.

As mentioned above, in this micro-grid system different transient faults at F1 locations have been considered. For all cases, the grid code requirement is met and it has been summarized in Table III which is further discussed with proper verification in the simulation section.

Table 3. Recovery time for different types of fault

\begin{tabular}{|c|c|c|}
\hline Fault location & Fault type & Recovery time (sec) \\
\hline F1 & 3LG & 0.80 \\
\hline F1 & 2LG & 0.45 \\
\hline F1 & 1LG & 0.24 \\
\hline F1 & 3LL & 0.80 \\
\hline
\end{tabular}

\section{Simulation Results}

Simulations for the ac-dc hybrid micro-grid system are performed in PSCAD/EMTDC [26] with 3LG, 2LG, 1LG faults at F1 location of the micro-grid. The fault is occurred at $1.1 \mathrm{sec}$ with duration of $0.1 \mathrm{sec}$. The fault is cleared at $1.2 \mathrm{sec}$. The schematic diagram of the model system with detailed control strategy is shown in fig. 4.

In Fig. 5, Real and reactive power through the converters, grid voltage, total generation and loads both ac and dc are and dc link voltage of the converter are shown. Figure 5 (a, b) depict the real and reactive power through converter 1 and 2 respectively. It is observed from Fig. 5(a,b) that before the transient fault, the converter 1 was in operation and the additional converter was switched off. So the alternate converter was not delivering any real and reactive power to the system. During transient, according to the control strategy, when the grid voltage drops to $90 \%$ of its pre-fault value, the alternate converter comes into operation and at $9^{\text {th }} \mathrm{sec}$ when the grid voltage reaches to close to 1.03 p.u. the converters again goes to its previous state. Breaker recloses at $2 \mathrm{sec}$. From Fig. 5(a, b), it can be clearly observed that the additional converter reaches to its prefault state and it only operates during the transient fault condition and provides additional reactive power to support in withstanding severe voltage dip in the system.

Figure 5(c) shows the grid voltage of the micro-grid system. It is observed that the grid voltage recovers $90 \%$ of its pre-fault value within $0.80 \mathrm{sec}$ which fulfills the grid code requirement. Figure 5(d) represents the apparent power of the both converters which stays within the rated value. 


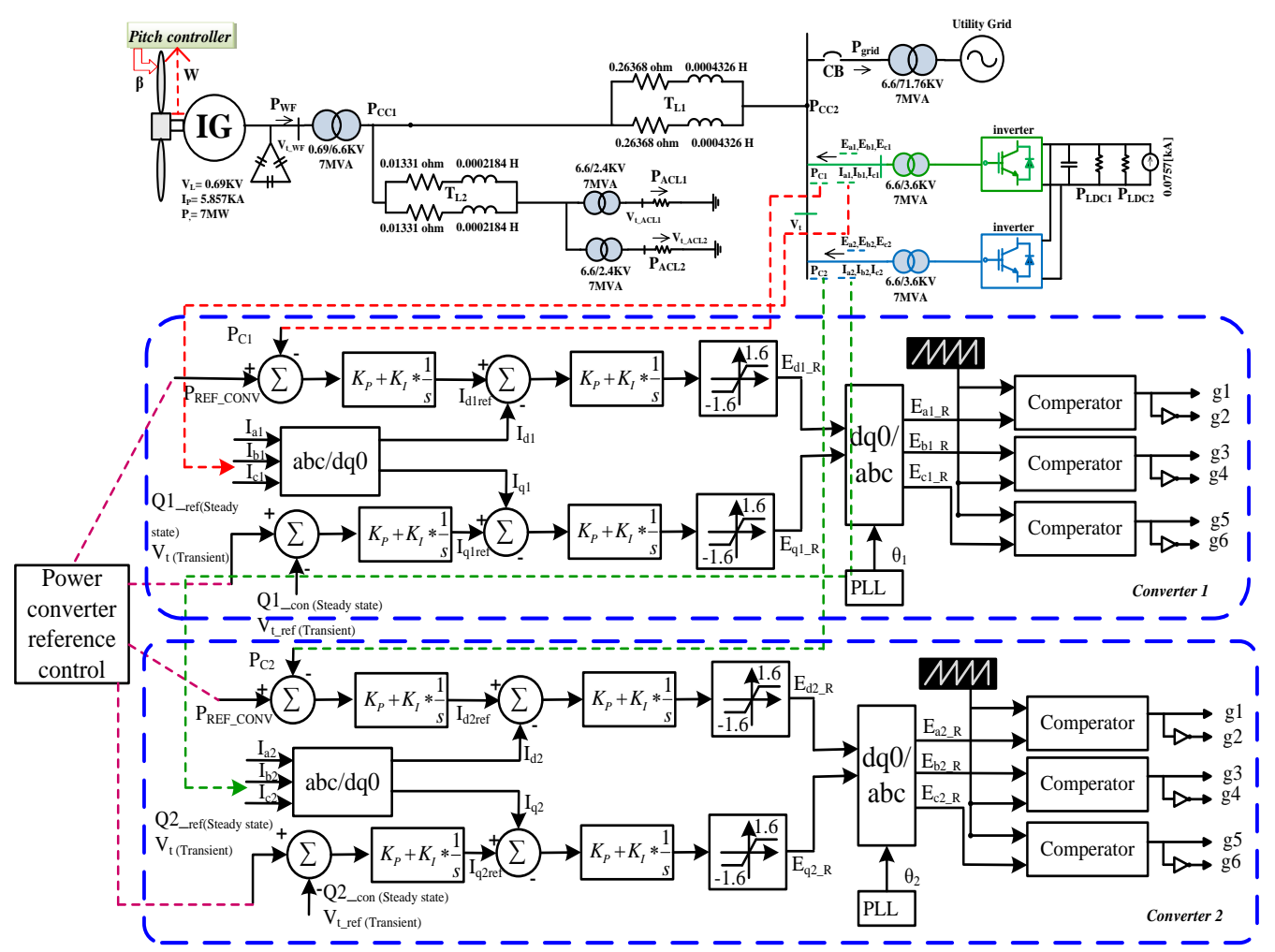

Fig. 4. Schematic diagram of the model system with converter control strategy

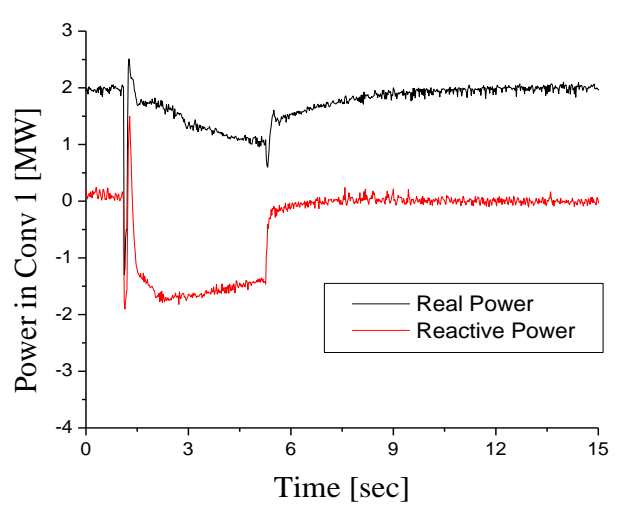

(a)

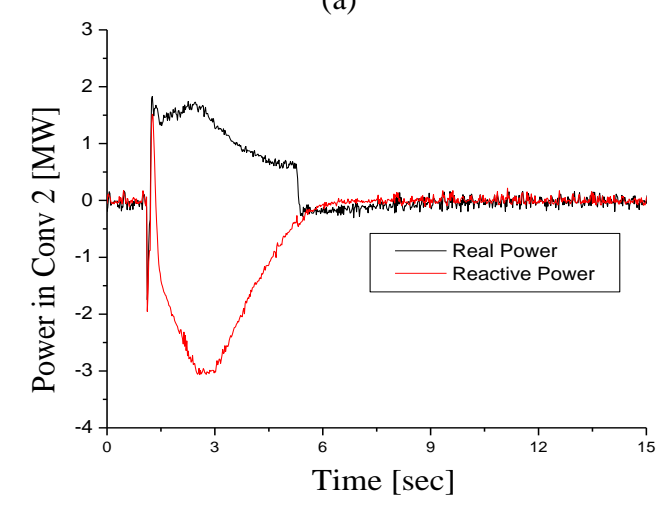

(b)

Fig. 5. System responses in Micro-grid system with $3 \mathrm{~L}$ $G$ fault (a) Power through converter1 (b) Power through converter 2 (c) Grid voltage

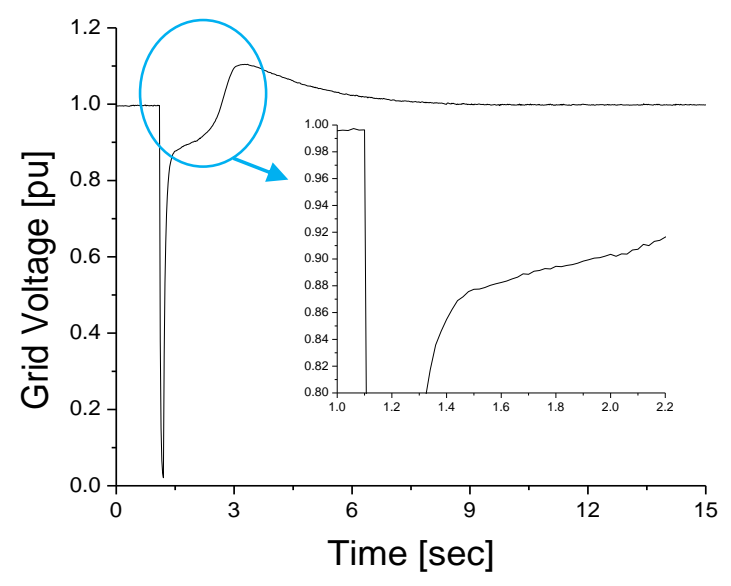

(c)

Fig. 5. (Continued)

In Fig. 6, grid voltage at F1 location for 2LG, 1LG and $3 \mathrm{LL}$ faults are shown as well. The recovery time to reach $90 \%$ of its pre-fault value after the transient faults meets the grid code requirement. The recovery times shown in the simulations are summarized in Table II as mentioned before. The simulation results verify that the hybrid micro-grid system can withstand severe voltage dip during the transient disturbances during different transient faults. 


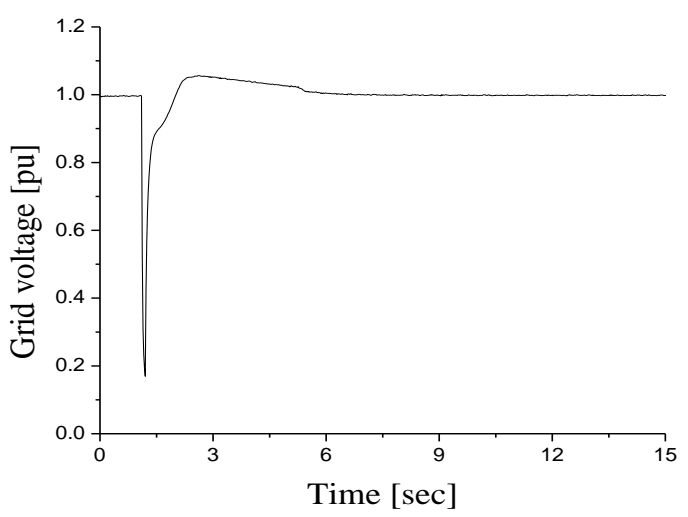

(a)

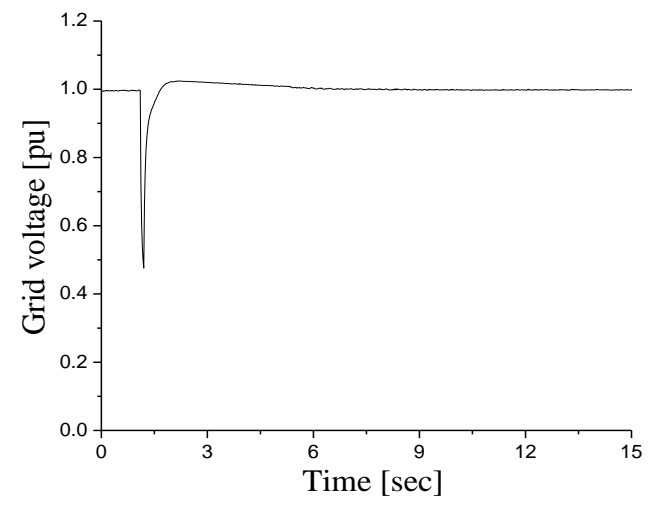

(b)

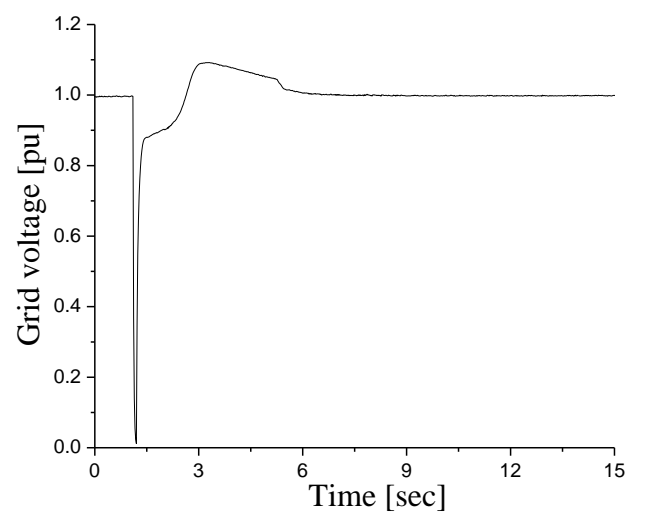

(c)

Fig. 6. Grid Voltage responses in Micro-grid system at F1 location during (a) $2 \mathrm{LG}$ (b) $1 \mathrm{LG}$ (c) $3 \mathrm{LL}$ faults

\section{Conclusion}

The main focus of this paper is to have the capability of low voltage ride through (LVRT) for the multiple parallel converter based ac-dc hybrid micro-grid system. The effectiveness of the proposed control system has been verified by simulation analysis. It is observed that during pre-fault condition, single power converter operates whereas during transient condition, the additional power converter delivers necessary reactive power along with the main converter and the micro-grid system can withstand severe voltage dip and the recovery time for the grid voltage to regain $90 \%$ of its pre-fault value meets the grid code requirement, which validates the effectiveness of the proposed control strategy. The multiple power converter scheme of the ac-dc hybrid micro-grid system enhances the stability during transient conditions.

\section{References}

[1] S.M. Muyeen, M. H. Ali, R. Takahashi, T. Murata, J. Tamura, Y. Tomaki, A. Sakahara and E. Sasano, "Comparative study on transient stability analysis of wind turbine generator system using different drive train models," IET Renew. Power Gener. Vol. 1, No. 2, pp. 131-141, June 2007.

[2] "Grid Code High and Extra High Voltage," Tech. Rep., E.ON Netz GmgH Bayreuth, 2003 [Online]. Available: http://eonnetz.com.

[3] M. Molinas, J. A. Suul and T. Undeland, "Low Voltage Ride Through of Wind Farms With Cage Generators: STATCOM versus SVC," IEEE Trans. Power Elect, Vol. 23, No. 3, pp. 1104-1117, MAY 2008.

[4] J. F. Conroy and R. Watson, "Low-voltage ride-thorough of a full converter wind turbine with permanent magnet generator," IET Renew. Power Gener., Vol. 1, No. 3, pp. 182189, Sept. 2007.

[5] C. Abbey and G. Joos, "Effect of Low Voltage Ride Through (LVRT) Characteristic on Voltage Stability," in IEEEPower Engineering Society General Meeting, Vol. 2, pp. 1901-1907, 2005.

[6] Anne-Marie Borbely and Jan F. Kreider, Distributed Generation: Power Paradigm for the New Millennium; CRC Press., 2001.

[7] R. H. Lasseter, "MicroGrids," PES Winter Meeting, vol. 1, pp. 305-308, 2002.

[8] X. Liu, P. Wang and P. C. Loh, "A Hybrid AC/DC Microgrid and Its Coordination Control", IEEE Trans. Smart Grid, Vol. 2, No. 2, pp. 278-286, June 2011.

[9] Y. Ito, Z. Yang and H. Akagi, "DC micro-grid based distribution power generation system," in Proc. IEEE Int. Power Electron. Motion Control Conf., Aug. 2004, Vol. 3, pp. 1740-1745.

[10] X. Liu, P. Wang and P. C. Loh, "A Hybrid AC/DC MicroGrid," IPEC, 2010, pp. 746-751, 27-29 Oct. 2010.

[11] M. N. Ambia, A. Durra, S.M. Muyeen, Centralized Power Control Strategy for AC-DC Hybrid Micro-grid System using Multi-converter Scheme, Proc. IECON 2011- 37th Annual Conference on IEEE Industrial Electronics Society, Melbourne, Australia, Nov. 7-10, 2011, pp. 843-848.

[12] M. N. Ambia, A. Durra, C. Caruana, and S.M. Muyeen, Islanding operation of hybrid micro-grid system with power management control scheme, 11th IASTED European conference on Power and Energy Systems (EURO PES 2012), Italy, Jun. 25-27. 2012.

[13] S. Santos, and H. T. Le, "Fundamental Time-Domain Wind Turbine Models for Wind Power Studies," Renewable Energy, Vol. 32, pp. 2436-2452, 2007.

[14] O. Wasynczuk etc, Dynamiac behavior of a class of wind turbine generators during random wind fluctuations, IEEE Trans. on Power Apparatus and Systems, PAS-100(6), pp.2854-2854, June 1981. 
[15] K.E. Okedu, S.M. Muyeen, R. Takahashi, and J. Tamura, "Comparative Study between Two Protection Schemes for DFIG-based Wind Generator," Proceedings of International Conference on Electrical Machines and Systems, pp. 62-67, 10-13 Oct. 2010.

[16] R. Takahashi, J. Tamura, M. Futami, M. Kimura and K. Idle, "A New Control Method for Wind Energy Conversion System Using Double Fed Synchronous Generators," IEEJ Trans. Power and Energy, Vol.126, No.2, pp.225-235, 2006 (in Japanese).

[17] T. Sun, Z. Chen and F. Blaabjerg, "Transient Stability of DFIG Wind Turbines at an External Short Circuit Fault," Wind Energy Journal, Vol. 8, pp. 345-360, 2005.

[18] R. D. Fernandez, P.E. Battaiotto, and R. J. Mantz, "Wind Farm NonLinear Control for Damping Electromechanical Oscillations of Power Systems," Renewable Energy, Vol. 33, pp. 2258-2265, 2008.

[19] K. E. Okedu, S.M. Muyeen, R. Takahashi and J. Tamura, "Stabilization of Wind Farms by DFIG-based Variable Speed Wind Generators," International Conference on Electrical Machines, pp. 464-469, 2010.

[20] G. Vachtsevanos and K. Kalaitzakis, "A Hybrid Photovoltaic Simulator for Utility Interactive Studies," IEEE Trans. Energy Conversion, Vol. EC-2, No. 2, pp. 227-231, June 1987.

[21] M.J Khan and M. T. Iqbal, "Dynamic Modeling and Simulation of a Small Wind-Fuel Cell Hybrid Energy System," Renewable Energy, pp. 421-439,2005.

[22] T. Tsao, P. Chen and H. Chen, "Dynamic Modeling and Simulation of Hybrid Power Systems Based on Renewable Energy", International conference on Energy and Environment Technology, pp. 602-605, Oct. 2009.

[23] S. M. Muyeen, J. Tamura, and T. Murata, "Stability Augmentation of a Grid-connected Wind Farm," SpringerVerlag London, ISBN 978-1-84800-315-6, October 2008.

[24] E.On NETZ Gmbh, "Grid Connection Regulation for High and Extra High Voltage," 2006.

[25] K.E Okedu, S.M.Muyeen, R. Takahashi and J. Tamura, "Participation of facts in stabilizing DFIG with crowbar during grid fault based on grid codes," IEEE GCC conference and Exhibition, pp. 365-368, Feb. 2011.

[26] "PSCAD/EMTDC Manual," Manitoba HVDC Research Center, 1994.

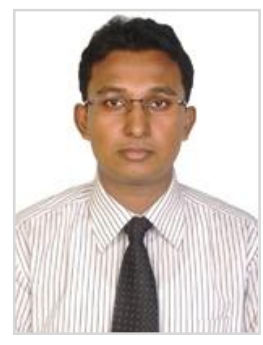

Mir Nahidul Ambia received his B.Sc. Eng. Degree from Islamic University of Technology (IUT), Bangladesh, in 2008 in Electrical and Electronic Engineering and M. Sc. degree from The Petroleum Institute, United Arab Emirates, in 2012 in Electrical Engineering. After his B. Sc., he worked in Eastern University, Bangladesh as Lecturer from February 2009 to August 2010. His M. Sc. research work focused on reliability enhancement and power management of micro-grid system. His research interests are hybrid micro-grid system, islanding operation, grid resynchronization, energy storage system (ESS) and Renewable Energy. Mir Nahidul Ambia is the student member of IEEE.

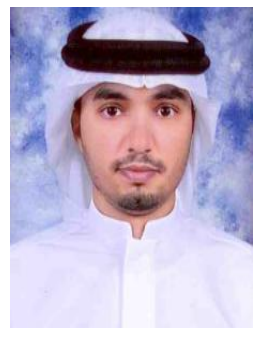

Dr. Ahmed Al-Durra received the B.S., M.S., and $\mathrm{PhD}$ in Electrical and Computer Engineering from the Ohio State University in 2005, 2007, and 2010, respectively. For his M. Sc. degree, he investigated the application of several nonlinear control techniques on automotive traction PEM fuel cell systems. He conducted his $\mathrm{PhD}$ research at the Center for Automotive Research in the Ohio State University. His PhD work was on the applications of modern estimation and control theories to automotive propulsion systems." At the present, he is working as Assistant Professor in Electrical Engineering Department at the Petroleum Institute, Abu Dhabi. His research interests are application of estimation and control theory in power system stability and control, energy storage system (ESS), and renewable energy. Dr. Ahmed is a member of IEEE, and ASME.

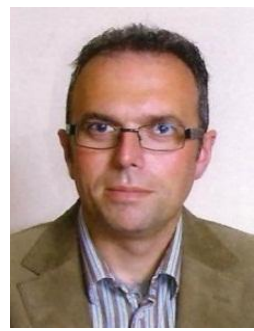

Cedric Caruana received the $\mathrm{PhD}$ Degree in Electrical Engineering from the University of Nottingham, Nottingham, UK in 2004. He was with Carlo Gavazzi (Malta) Ltd and ST Microelectronics (Malta) Ltd working as a process engineer and senior test

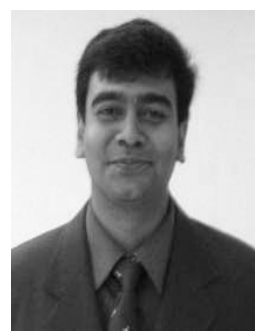

Dr. S. M. Muyeen received his B.Sc. Eng. Degree from Rajshahi University of Engineering and Technology (RUET), Bangladesh formerly known as Rajshahi Institute of Technology, in 2000 and M. Sc. Eng. and Dr. Eng. Degrees from Kitami Institute of Technology, Japan, in 2005 and 2008, respectively, all in Electrical and Electronic Engineering. His $\mathrm{PhD}$ research work focused on wind farm stabilization from the viewpoint of LVRT and frequency fluctuation. After completing his Ph.D. program he worked as a Postdoctoral Research Fellow under the versatile banner of Japan Society for the Promotion of Science (JSPS) from 2008-2010 at the Kitami Institute of Technology, Japan. At the present, he is working as Assistant Professor in Electrical Engineering Department at the Petroleum Institute, Abu Dhabi. His research interests are power system stability and control, electrical machine, FACTS, energy storage system (ESS), Renewable Energy, and HVDC system. He has published over 100 international papers. He has published four books as an author or editor. Dr. Muyeen is the member of IEEJ and IEEE. 